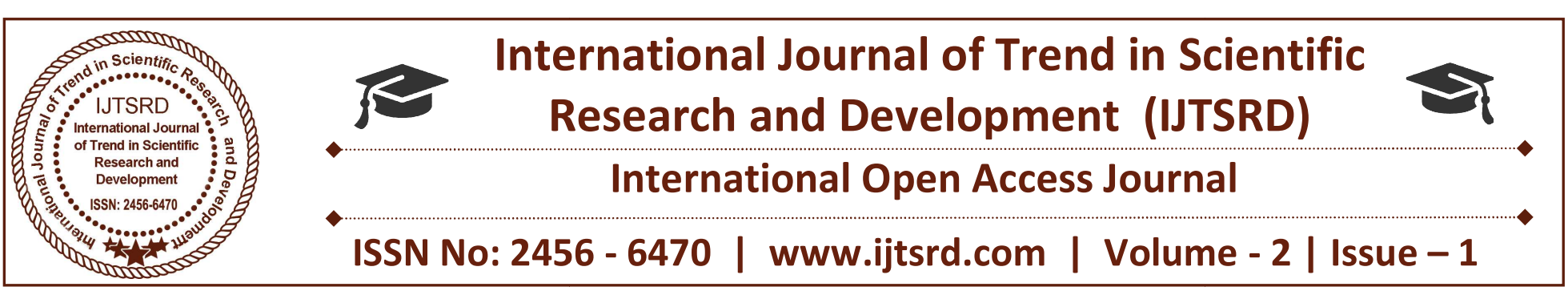

\title{
Optimization of Anaerobic Mechanism using Response Surface Methodology (RSM) to treat Pulp and Paper Industry Wastewater : A Review
}

\author{
Ravichandran $\mathbf{P}$ \\ Assistant Professor, Department of \\ Civil Engineering, FEAT, \\ Annamalai University, Annamalai \\ Nagar, Tamil Nadu, India
}

\author{
Karthik C \\ M.E. Scholar, Department of Civil \\ Engineering, FEAT, Annamalai \\ University, Annamalai Nagar, \\ Tamil Nadu, India
}

\author{
Balaji K \\ Assistant Professor, Department of \\ Civil Engineering, FEAT, \\ Annamalai University, Annamalai \\ Nagar, Tamil Nadu, India
}

\section{ABSTRACT}

Optimization plays a key role in environmental engineering parameters since the best system performance mainly is on optimum point or optimum range. The majority of wastewater treatment processes are multi-variable and optimization through the classical method is inflexible, unreliable and timeconsuming. Thus, response surface methodology (RSM), as a very efficient design and widely used technique, can be adapted for optimization of various parameters in wastewater treatment processes. RSM is a practical mathematical and statistical tool that can be employed for analyzing the effects of several independent factors on the treatment process in order to obtain the maximum benefit from the process. Recently, several water and wastewater treatment processes have been optimized for treatment different type of wastewaters via RSM including; textile dye wastewater, tannery wastewater, industrial paint wastewater, landfill leachate, olive oil wastewater, and palm oil mill effluent. The present study focuses on the usability and effectiveness of RSM for process parameters modeling and optimization in wastewater treatment studies. In this paper, some of the RSM studies were reviewed in order to verify the usability of RSM and its limitations.

Keywords: Design of experiments, Optimization, Pulp and Paper Industry, Response Surface Methodology, Wastewater.

\section{Introduction}

The paper industry is one of the largest industries in India, consuming large amount of water (Rajakumar et al. 2011; Bashir et al. 2012). Indian paper mills take a wide variety of cellulosic and non-cellulosic raw materials. The pulp and paper mill in India utilizes different cellulosic materials about $43 \%$ wood forest based, 28\% agro based and 29\% waste paper based on the total installed capacity (Balakrishnan 1999). These effluents are strongly coloured owing to the presence of lignin, resin, tannin and chlorophenolic compounds that are resistant to biodegradation. However, very few information are available on the applicability of treating real pulp and paper mill waste water by anaerobic digestion (especially model/pilot/full-scale HUASBR). Anaerobic digestion is used in treatment of wastewater obtained from olive mill (Mohamed 1989), dairy (Nemerow et al. 1991), slaughter house (Mandal and Bandana 1996) and dye bath effluents (Carliell et al. 1996). But in case of Pulp and paper mill waste water, it is not used as widely as the activated sludge process (Pokhrel and Viraraghavan 2004). Hence, pulp and paper mill waste water needs detailed study. The Up flow anaerobic sludge blanket (UASB) reactor introduced by (Lettinga et al. 1980) has become a popular high-rate anaerobic treatment system throughout the world (Lettinga et al. 1993). In the journal article (Rindone et al. 1991), the Hybrid up flow anaerobic sludge blanket (HUASB) reactor is a new concept which is the hybridized version of an 
UASB reactor with a random packing media at the top of the reactor. In which upper portion of $50-70 \%$ is filled with either floating (or) stationary materials to retain some of the escaping biomass. This HUASB reactor combines the merits of UASB (Suspended growth system) and fixed film reactors (Attached growth system). This type of reactor is of particular value in a situation when the rate of sludge granulation is slow and there is a need to accelerate the reactor start-up (Badroldin et al. 2008). In recent years, HUASB reactor has proved to be a more versatile anaerobic treatment in treatment of industrial wastewater. Therefore an attempt will be taken to measure the treatability performance of HUASB reactor using pulp and paper mill wastewater (Hemalatha, Sanchitha and Keerthinarayana, 2014).

\section{Microbial Activities in the Anaerobic Process}

The number and types of microorganisms present in digesters are likely to depend upon the type of digester, its operating conditions and the waste composition. The metabolic stages involved in the production of methane from waste in Anaerobic Digestion occur in 4 distinct processes (Fig. 1);

\subsection{Hydrolysis}

Complex organic matter is decomposed into simple soluble organic molecules using water to split the chemical bonds between the substances. This is where solid complex organics, cellulose proteins, lignins, and lipids are broken down into soluble (liquid) organic fatty acids. The results are soluble monomers. Hydrolytic bacteria are responsible for the creation of monomers. Enzymes excreted from the bacteria, such as cellulase, protease, and lipase, catalyse hydrolysis. Therefore, the more complex the feedstock then the hydrolytic phase is relatively slow. A hydrolysis reaction where organic waste is broken down into a simple sugar, in this case glucose can be seen in the following Eq.1.

$$
\mathrm{C}_{6} \mathrm{H}_{10} \mathrm{O}_{4}+2 \mathrm{H}_{2} \mathrm{O} \rightarrow \mathrm{C}_{6} \mathrm{H}_{12} \mathrm{O}_{6}+2 \mathrm{H}_{2}
$$

\subsection{Fermentation/Acidogenesis}

The chemical decomposition of Carbohydrates, proteins and fats by enzymes, bacteria, yeasts in the absence of oxygen. Hydrolysis is immediately followed by the acid-forming phase of Acidogenesis. Here acidogenic bacteria turn products of hydrolysis into mostly short chain (volatile) acids (e.g. formic or lactic), ketones (e.g. ethanol or acetone) and alcohols. The specific concentrations of products formed here vary with the type of bacteria, culture conditions, such as temperature and $\mathrm{pH}$.

\subsection{Acetogenesis}

The fermentation products are converted into acetate hydrogen and carbon dioxide by so called acetogenic bacteria. Here the Biological Oxygen Demand (BOD) and Chemical Oxygen Demand (COD) are reduced. Acetogenesis occurs through carbohydrate fermentation which acetate is the main product, and other metabolic processes. In Eq. 2 reaction in the acid-forming stages is shown below, glucose is converted to ethanol.

$$
\mathrm{C}_{6} \mathrm{H}_{12} \mathrm{O}_{6} \leftrightarrow 2 \mathrm{CH}_{3} \mathrm{CH}_{2} \mathrm{OH}+2 \mathrm{CO}_{2}
$$

\subsection{Methanogenesis}

Methane (CH4) is formed from acetate and hydrogen/carbon dioxide by methanogenic bacteria. Most methanogenic bacteria utilize $\mathrm{H} 2 \& \mathrm{CO} 2$, but species of only two genera Methanosarcina and Methanorthrix, can produce methane from acetic acid. The acetogenic bacteria grow in close association with the methanogenic bacteria during the 4 th stage process (Osman, 2014).

\subsection{Advantages of Anaerobic fermentation}

1. It can treat a wide range of organic wastes including industrial wastewater

2. No odour nuisance during the process and the reduction approximately $80 \%$ of the odour potential.

3. It is relatively small in size to the amount of waste treated.

4. Anaerobic fermentation projects can directly boost the local rural economy through creating jobs in the anaerobic fermentation development and indirectly through increasing disposable income in rural areas.

5. Reducing land and waste pollution: Poor disposal of wastewater can cause land and ground water pollution. Anaerobic fermentation creates integrated management system which reduces the likelihood of this happening and reduces the likelihood of fines been imposed of such pollution.

6. Anaerobic fermentation provides onsite energy for the process

The biogas produced is a renewable energy source and used as a transport fuel or to produce electricity displaces fossil fuel energy and they're by reducing the emissions of green house and acidifying gasses 
1. Anaerobic digestion is also a technology that can make a significant contribution to the management of organic waste.

2. The fiber form the anaerobic digestion process can be used as a good soil conditioner and the liquor can be used as a fertilizer

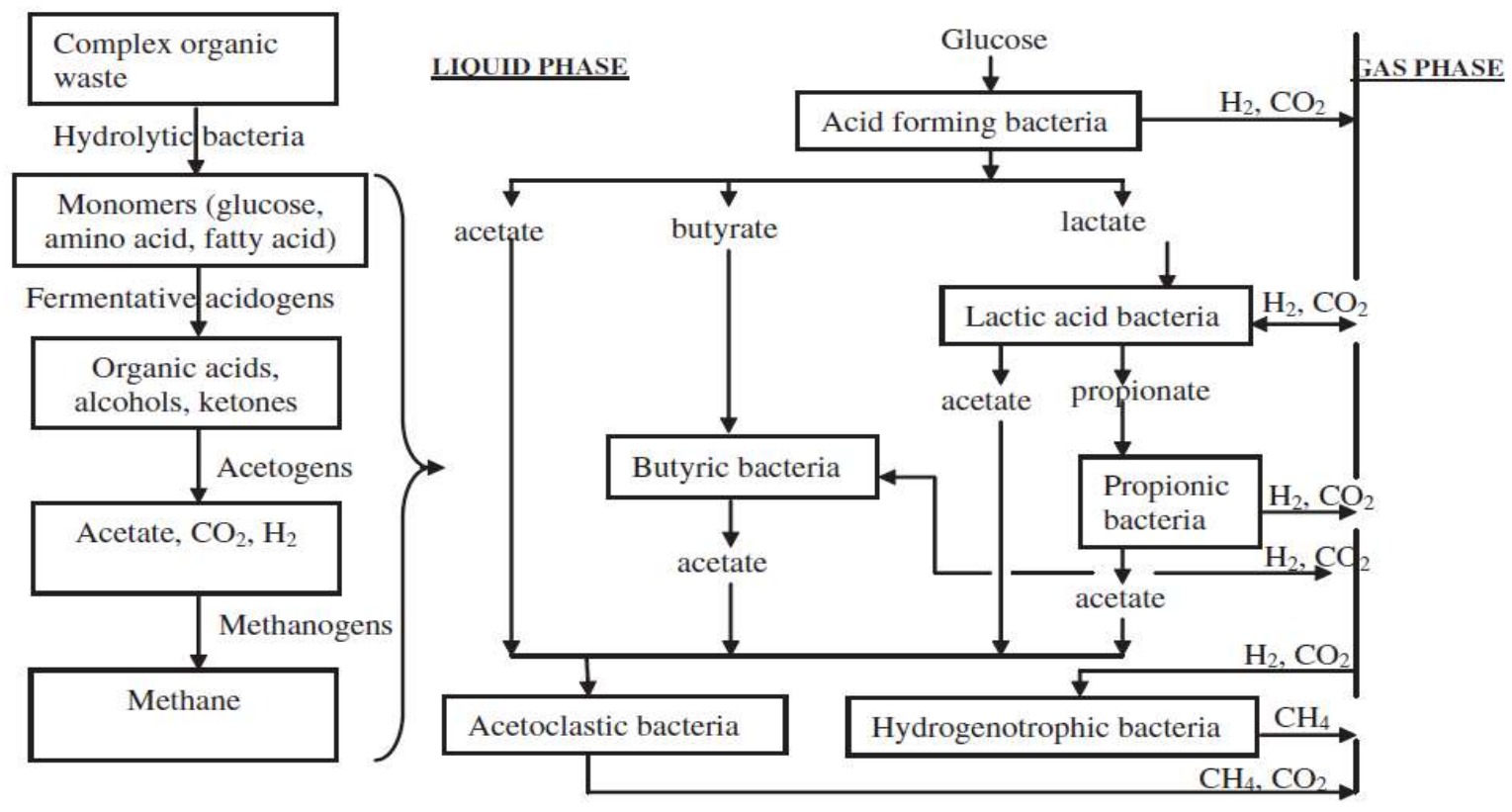

Figure 1: Process flow of anaerobic digestion mechanism

3. Upflow anaerobic sludge blanket reactor (UASBR)

One of the most notable developments in anaerobic treatment process technology is the upflow anaerobic sludge blanket (UASB) reactor (Lettinga et al., 1980) with its wide applications in relatively dilute municipal wastewater treatment (Tchobanoglous et al., 2003). Influent flow distributed at the bottom of the UASB reactor travels in an upflow mode through the sludge blanket and passes out around the edges of a funnel which provides a greater area for the effluent with the reduction in the upflow velocity, enhancement in the solids retention in the reactor and efficiency in the solids separation from the outward flowing wastewater (Ersahin and Ozgun, no date). Granules which naturally form after several weeks of the reactor operation consist primarily of a dense mixed population of bacteria that is responsible for the overall methane fermentation of substrates (Rittmann \& McCarty, 2001). Good settleability, low retention times, elimination of the packing material cost, high biomass concentrations (30000-80000 mg/L), excellent solids/liquid separation and operation at very high loading rates can be achieved by UASB systems (Speece, 1996). The only limitation of this process is related to the wastewaters having high solid content which prevents the dense granular sludge development (Tchobanoglous et al., 2003). Design OLR is typically in the range of 4 to $15 \mathrm{~kg} \mathrm{COD} / \mathrm{m} 3$.day (Rittmann \& McCarty, 2001).

\section{Major pulp-and-paper processes}

The main processes in pulp manufacturing and paper making are divided into five major groups including mechanical, chemical, chemo-mechanical, and thermomechanical pulping as well as papermaking, each producing a high volume of wastewater with special characteristics.

\subsection{Wastewater production in the pulp-and-paper processes}

Wood preparation, pulp washing, pulp bleaching and paper making processes as well as the digester house are the major wastewater producers in the pulp-andpaper industry (The World Bank Group, 1999). The generated wastewaters have a high content of BOD and various concentrations of other contaminants that depend on the types of applied processes. For instance, wood preparation wastewater has suspended solids, BOD, dirt, and fibers while the produced wastewater in the digesters house contains resins, fatty acids, color, BOD, COD, AOX, and VOCs (Pokhrel and 
Viraraghavan, 2004). The magnitude of GHG emission in the WWTPs depend on the concentrations of nutrients in wastewater, reactor operating temperature, type of treatment processes employed and the contaminant removal efficiency(Ashrafi et al., 2013b).

\subsection{Wastewater treatment}

The growing concerns about the use of fresh water, increased economic considerations and stringent environmental regulations have highlighted the importance of water use and efficient wastewater treatment in the pulp-and-paper industry. The recycling and reuse of the generated wastewater after its proper treatment is the key to reduce fresh water use. This procedure will minimize external discharges to the environment while advancing environmental conservation by reducing fresh water consumption. In view of this, the main objective of WWTPs is to remove contaminants from wastewater using a series of physicochemical, biological, and integrated treatment processes. Ashrafi et al. (2013a; 2013b) developed comprehensive mathematical models (steady-state and dynamic models) to estimate the generated GHG emission by WWTPs. In the development of these models, it was assumed that the bioreactors are completely mixed (Ashra, Yerushalmi and Haghighat, 2015):

Accumulation $=$ influent - effluent + net growth (production by reaction)

\section{Response Surface Methodology}

The Response Surface Methodology (RSM) emerged in the 1950s (BOX et al., 1951; BOX

et al., 1951) within the context of Environmental Engineering in an attempt to construct empirical models able to find useful statistical relationships between all the variables making up an industrial system. Optimization plays a key role in this domain and parameters to optimize the system's performance. Majority of the wastewater treatment processes are multi-variable and optimization through the classical method is inflexible, unreliable and time-consuming. Thus, an alternative method which will be more effective and can be adapted for parameter optimization of various wastewater treatment processes is favored. Response surface methodology (RSM) is one of the most efficient and widely used mathematical and statistical tools for system performance optimization. RSM can be employed to optimize and analyze the effects of several independent factors on a treatment process to obtain the maximum output. This methodology is based on experimental design with the final goal of evaluating optimal functioning of industrial facilities, using minimum experimental effort. Here, the inputs are called factors or variables and the outputs represent the response that generates the system under the causal action of the factors. Afterwards, the use of the RSM was shown in the design of new processes and products. In recent years it is being applied successfully in other scientific fields such as biology, medicine, and economy (Jiménezcontreras and Torres-salinas, 2009). MYERS et al. (2004) has exhaustively reviewed the literature in the sense, describing the developments and applications of this methodology. Very recently, RSM has been used even to validate new experimental methods (JURADO et al., 2003).

Besides analyzing the independent variables effects, this experimental methodology also generates a mathematical model. The graphical viewpoint of the mathematical model has led to the term RSM. The relationship between the responses and the inputs is given in Eq. (3):

$$
Y=f\left(X_{1}, X_{2}, X_{3}, \ldots, X_{n}\right) \pm \varepsilon
$$

Where $\mathrm{Y}$ is the response, $\mathrm{f}$ is the unknown function of response, $\mathrm{x}_{1}, \mathrm{x}_{2}, \mathrm{x}_{3} \ldots \ldots \mathrm{x}_{\mathrm{n}}$ are the input variables which can affect the response, $\mathrm{n}$ is the number of the independent variables and $\varepsilon$ is the statistical error that represents other sources of variability not accounted for by $f$. After selection of the design, the model equation is defined and coeffecnts of the model equation are predicted.

As the result of sequential model sum of squares suggestion of software and software suggestion, the quadratic model was selected. In the case that total number of experiments is $\mathrm{n}$; the response surface can be expressed as follows using matrix notation of the model.

$$
\mathrm{Y}=\mathrm{X} \beta \pm \varepsilon
$$

Where

$$
\left\{\begin{array}{c}
y_{1} \\
y_{2} \\
\vdots \\
y_{n}
\end{array}\right\}=\left\{\begin{array}{cccc}
1 x_{11} & x_{12} & \cdots & x_{1 k} \\
1 x_{21} & x_{22} & \cdots & x_{2 k} \\
\vdots & \vdots & \ddots & \vdots \\
1 x_{n 1} & x_{n 2} & \cdots & x_{n k}
\end{array}\right\}\left\{\begin{array}{c}
\beta_{1} \\
\beta_{2} \\
\vdots \\
\beta_{n}
\end{array}\right\}+\left\{\begin{array}{c}
\varepsilon_{1} \\
\varepsilon_{2} \\
\vdots \\
\varepsilon_{n}
\end{array}\right\}
$$


Where $\varepsilon$ is random error.

The following equation is for calculating the total number of experiments

$$
\mathrm{N}=\mathrm{n}^{3}+2 \mathrm{n}+\mathrm{nc}
$$

Where $\mathrm{N}$ is the total number of experiments and $\mathrm{n}$ is the number of factors.

The selected independent variables were coded according to equation (4)

$$
X_{i}=\frac{X_{i}-X_{0}}{\Delta X}
$$$$
i=1,2, \ldots \ldots . k
$$

Where $X_{i}$ refers to coded value of the $i^{\text {th }}$ independent variable, $X_{0}$ is the value of $X_{i}$ at the center point and $\Delta \mathrm{X}$ is the step change value [12] the response function $(\mathrm{Y})$ is measured as the yield in processes. The model used in RSM is commonly a full quadratic equation in the diminished form of this equation. The second order model can be written as follows.

$$
Y=\beta_{0}+\sum_{i=1}^{n} \beta_{i} x_{i}+\sum_{i=1}^{n} \beta_{i i} x_{i}^{2}+\sum_{i \neq j=1}^{n} \beta_{i j} x_{i} x_{i j}+\varepsilon
$$

Where $\beta 0$ is the value of the fixed response at the center point of the design; $\beta \mathrm{i}, \beta \mathrm{ii}$, and $\beta \mathrm{ij}$ are the linear, quadratic and interaction effect regression terms, respectively; xi denotes the level of the independent variable; $\mathrm{n}$ is the number of independent variables; and $\varepsilon$ is random error. Normally, a second order polynomial equation was derived as:

$$
Y=\beta_{0}+\beta_{1} x_{1}+\beta_{2} x_{2}+\beta_{3} x_{3}+\beta_{13} x_{1} x_{3}+\beta_{23} x_{2} x_{3}+\beta_{11} x_{1}^{2}+
$$

\subsection{RSM application in optimization of wastewater treatment processes}

In this section, several published RSM studies in the last few years were reviewed focusing on the usability of RSM for optimization of various types of wastewater treatment processes. Table 1 summarizes different

\begin{tabular}{|c|c|c|c|c|}
\hline $\begin{array}{l}\text { Wastewater } \\
\text { type }\end{array}$ & $\begin{array}{l}\text { Treatment } \\
\text { technique }\end{array}$ & Independent variables & Responses & Ref. \\
\hline $\begin{array}{c}\text { Textile } \\
\text { wastewater }\end{array}$ & $\begin{array}{l}\text { Electrochemical } \\
\text { Oxidation }\end{array}$ & $\begin{array}{l}\text { pollution load, } \\
\text { applied potential, electrolyte } \\
\text { concentration, } \\
\text { temperature, and reaction time }\end{array}$ & $\begin{array}{l}\text { COD, color turbidity } \\
\text { removals }\end{array}$ & [19] \\
\hline Textile dyes & Adsorption & $\begin{array}{l}\text { Initial dye concentration, initial } \\
\text { solution } \mathrm{pH} \text { and } \\
\text { temperature }\end{array}$ & $\begin{array}{l}\text { the amount of dye } \\
\text { adsorbed at } \\
\text { equilibrium }\end{array}$ & [39] \\
\hline $\begin{array}{l}\text { Landfill } \\
\text { leachate }\end{array}$ & $\begin{array}{l}\text { Coagulation- } \\
\text { Flocculation }\end{array}$ & coagulant dosage and $\mathrm{pH}$ & $\begin{array}{l}\text { COD, turbidity, color, } \\
\text { and TSS removals }\end{array}$ & {$[15]$} \\
\hline $\begin{array}{l}\text { Landfill } \\
\text { leachate }\end{array}$ & Fenton Oxidation & $\begin{array}{c}\mathrm{pH}, \text { Reaction time, Initial } \\
\text { concentrations of } \mathrm{H} 2 \mathrm{O} 2 \text {, and Ferrous } \\
\text { ion concentration }\end{array}$ & $\begin{array}{l}\text { COD, color and } \\
\text { iron removals }\end{array}$ & {$[25]$} \\
\hline $\begin{array}{l}\text { Landfill } \\
\text { Leachate }\end{array}$ & $\begin{array}{l}\text { Electrochemical } \\
\text { oxidation }\end{array}$ & $\begin{array}{l}\text { electrolyte } \\
\text { concentrations, current density and } \\
\text { reaction time }\end{array}$ & $\begin{array}{l}\text { COD and color } \\
\text { removals }\end{array}$ & {$[26]$} \\
\hline $\begin{array}{l}\text { Landfill } \\
\text { leachate }\end{array}$ & $\begin{array}{l}\text { Ion Exchange } \\
\text { (cation resin) }\end{array}$ & $\begin{array}{c}\text { Cation resin dosage, contact time, } \\
\text { shaking speed }\end{array}$ & Ammonia removal & {$[9]$} \\
\hline $\begin{array}{l}\text { Landfill } \\
\text { leachate }\end{array}$ & $\begin{array}{l}\text { Ion Exchange } \\
\text { (anion resin) }\end{array}$ & $\begin{array}{l}\text { anion resin dosage, contact time, } \\
\text { shaking speed, } \mathrm{pH}\end{array}$ & $\begin{array}{l}\text { COD, color, turbidity, } \\
\text { and SS removals }\end{array}$ & {$[10]$} \\
\hline $\begin{array}{c}\text { Pulp mill } \\
\text { wastewater }\end{array}$ & $\begin{array}{l}\text { Coagulation- } \\
\text { Flocculation }\end{array}$ & $\begin{array}{c}\text { coagulant dosage, flocculant dosage } \\
\text { and } \mathrm{pH}\end{array}$ & $\begin{array}{l}\text { turbidity removal, } \\
\text { lignin removal and } \\
\text { clean water recovery }\end{array}$ & {$[47]$} \\
\hline $\begin{array}{l}\text { Slaughterhouse } \\
\text { Wastewater }\end{array}$ & $\begin{array}{l}\text { Electrochemical } \\
\text { oxidation }\end{array}$ & $\begin{array}{c}\text { current density, reaction time and } \\
\text { influent COD }\end{array}$ & $\begin{array}{l}\mathrm{COD}, \mathrm{BOD} \text {, and color, } \\
\text { removal efficiencies } \\
\text { and effluent } \mathrm{pH}\end{array}$ & {$[5]$} \\
\hline
\end{tabular}
applications of RSM in optimizing various types of wastewater treatment techniques.

\section{Table 1: Various application of RSM in wastewater treatment process optimization}


International Journal of Trend in Scientific Research and Development (IJTSRD) ISSN: 2456-6470

\begin{tabular}{|c|c|c|c|c|}
\hline $\begin{array}{c}\text { Simulated } \\
\text { industrial } \\
\text { wastewater }\end{array}$ & $\begin{array}{c}\text { Photo-Fenton } \\
\text { process }\end{array}$ & $\begin{array}{c}\text { initial } \mathrm{pH} \text { values, concentration of } \\
\text { iron catalyst } \\
\text { and the concentration of } \mathrm{H} 2 \mathrm{O} 2 \text { type of } \\
\text { UV irradiation }\end{array}$ & Mineralization rate & {$[13]$} \\
\hline $\begin{array}{c}\text { Dairy } \\
\text { wastewater }\end{array}$ & $\begin{array}{c}\text { Electrochemical } \\
\text { oxidation }\end{array}$ & $\begin{array}{c}\text { current density, dosage of sodium } \\
\text { chloride }(\mathrm{NaCl}) \text { electrolysis time and } \\
\text { pH, }\end{array}$ & COD removal & {$[20]$} \\
\hline $\begin{array}{c}\text { Petroleum } \\
\text { refinery } \\
\text { effluent }\end{array}$ & $\begin{array}{c}\text { Upflow anaerobic } \\
\text { sludge blanket } \\
\text { (UASB) bioreactor }\end{array}$ & $\begin{array}{c}\text { hydraulic retention time (HRT) } \\
\text { influent COD, up flow velocity (Vup) }\end{array}$ & $\begin{array}{c}\text { COD removal, and } \\
\text { rate of biogas } \\
\text { production }\end{array}$ & {$[35]$} \\
\hline $\begin{array}{c}\text { Oily } \\
\text { emulstewater }\end{array}$ & $\begin{array}{c}\text { Electro- } \\
\text { coagulation }\end{array}$ & $\begin{array}{c}\text { Current density, pH, and } \\
\text { Electrocoagulation time }\end{array}$ & $\begin{array}{c}\text { turbidity and COD } \\
\text { removals }\end{array}$ & {$[45]$} \\
\hline $\begin{array}{c}\text { Drinking water } \\
\text { Coagulation- } \\
\text { flocculation }\end{array}$ & coagulant dose and pH & $\begin{array}{c}\text { removal efficiency of } \\
\text { turbidity } \\
\text { and dissolved organic } \\
\text { carbon (DOC) }\end{array}$ & {$[46]$} \\
\hline $\begin{array}{c}\text { Olive oil mill } \\
\text { wastewater }\end{array}$ & $\begin{array}{c}\text { Fenton's } \\
\text { peroxidation }\end{array}$ & $\begin{array}{c}\text { he ratio of hydrogen peroxide-to- } \\
\text { Fe(II) Fe(II) concentration, and } \\
\text { H2O2 concentration }\end{array}$ & $\begin{array}{c}\text { COD, total phenolics } \\
\text { (TP), color and } \\
\text { aromatocity removal }\end{array}$ & {$[1]$} \\
\hline
\end{tabular}

Table 2: Feasibility of different treatment method for different wastewater sources

\begin{tabular}{|c|c|c|c|c|c|c|}
\hline Wastewater type & Independent variables & Responses & Reactor & $\begin{array}{l}\text { Start up } \\
\text { period }\end{array}$ & $\begin{array}{c}\text { Typical } \\
\text { loading } \\
\text { rates (kg } \\
\text { COD/m3 } \\
\text { day) }\end{array}$ & $\begin{array}{c}\text { HRT } \\
\text { (d) }\end{array}$ \\
\hline Textile wastewater & $\begin{array}{c}\text { Pollution load, } \\
\text { temperature, and reaction } \\
\text { time }\end{array}$ & $\begin{array}{l}\text { COD, color } \\
\text { turbidity } \\
\text { removals }\end{array}$ & CSTR & - & $0.25-3$ & $10-60$ \\
\hline Pulp mill wastewater & $\begin{array}{c}\text { Pollution load, } \\
\text { temperature, and reaction } \\
\text { time }\end{array}$ & $\begin{array}{l}\text { turbidity } \\
\text { removal, } \\
\text { lignin } \\
\text { removal and } \\
\text { clean water } \\
\text { recovery }\end{array}$ & UASBR & $4-16$ & $10-30$ & $0.5-7$ \\
\hline Dairy wastewater & $\begin{array}{l}\text { current density, dosage of } \\
\text { sodium chloride }(\mathrm{NaCl}) \\
\text { electrolysis time and } \mathrm{pH}\end{array}$ & $\begin{array}{c}\text { COD } \\
\text { removal }\end{array}$ & AFB & $3-4$ & $1-100$ & $0.2-5$ \\
\hline $\begin{array}{c}\text { Subjected to field } \\
\text { conditions }\end{array}$ & & & & & & \\
\hline
\end{tabular}

\section{CONCLUSION}

Response surface methodology (RSM) is a widely used technique which can be adapted for parameters optimization. Statistical and diagnostics analysis indicated that RSM is a reliable tool to optimize of process parameters. RSM is successfully applied for optimization of several wastewater treatment processes. In the current study, s RSM method and some of its applications that published recently were reviewed in order to verify the usability of RSM and its limitations. 
It was observed that RSM has several advantages in wastewater treatment process optimization. However, in most of the reviewed articles that implement RSM for optimization of wastewater treatment processes, there is not sufficient or adequate preliminary work in regards to the range of process variables. This could lead to inaccurate outcome.

\section{References:}

1) Ahmadi, M.; Vahabzadeh, F.; Bonakdarpour, B.; Mofarrah, E.; Mehranian, M: Application of the central composite design and response surface methodology to the advanced treatment of olive oil processing wastewater using Fenton's peroxidation, Journal of Hazardous Materials 123 (2005) 187195.

2) Ashra, O., Yerushalmi, L. and Haghighat, F. (2015) 'Wastewater treatment in the pulp-and-paper industry: A review of treatment processes and the associated greenhouse gas emission'. doi: 10.1016/j.jenvman.2015.05.010.

3) Ashrafi, O., Yerushalmi, L., Haghighat, F., 2013. Greenhouse gas emission by wastewater treatment plants of the pulp and paper industry e modeling and simulation. Int. J. Greenh. Gas. Control 17, 462e472. Ashrafi, O., Yerushalmi, L., Haghighat, F., 2014. Greenhouse

4) Ashrafi, O., Yerushalmi, L., Haghighat, F., 2013 a. Application of dynamic models to estimate greenhouse emission by wastewater treatment plants of the pulp and paper industry. Environ. Sci. Pollut. Res. 20, 1858e1869.

5) Awang, Z.B.; Bashir, M.J.K., Kutty, S.R.M.; Isa, M.H. Post-Treatment of Slaughterhouse Wastewater using Electrochemical Oxidation. Research Journal of Chemistry and Environment, 15 (2011) 229-237.

6) Badroldin, N.A., Latiff, A.A., Karim, A.T., Fulazzaky, M.A., "Palm oil mill effluent (POME) treatment using Hybrid Upflow Anaerobic Sludge Blanket (HUASB) reactors; Impact on COD removal and organic loading rates",Engineering Postgraduate Conference (EPC), 2008.

7) Balakrishnan, K., "India pulp and paper pollution control”, New Delhi report, 1999.

8) Bashir, M. J. K. et al. (no date) 'AN OVERVIEW OF WASTEWATER TREATMENT PROCESSES OPTIMIZATION USING RESPONSE SURFACE METHODOLOGY ( RSM )'.
9) Bashir, M.J.K.; Aziz, H.A.; Yusoff, M.S.; Adlan, M.N: Application of response surface methodology (RSM) for optimization of ammoniacal nitrogen removal from semi-aerobic landfill leachate using ion exchange resin, Desalination 254 (2010)154161.

10) Bashir, M.J.K.; Aziz, H.A.; Yusoff, M.S.; Aziz, S.Q.; Mohajeri, S:Stabilized Sanitary Landfill Leachate Treatment Using Anionic Resin: Treatment optimization by Response Surface Methodology. Journal of Hazardous Materials, 182 (2010)115-122.

11) BOX, G.E.P., HUNTER, J.S. (1951): Multifactor experimental designs for exploring response surfaces. Journal of the Royal Statistical Society, 13: $195-240$.

12) Carliell, C.M., Barclay, S.J., Buckley, C.A., "Treatment of exhausted reactive dyebath effluent using anaerobic digestion-Laboratory and full scale trails", Water SA 22, pp.225-233, 1996.

13) Dopar, M.; Kusic. H.; Koprivanac, N.; Treatment of simulated industrial wastewater by photo-Fenton process.Part I: The optimization of process parameters using design of experiments (DOE). Chemical Engineering Journal, 173 (2011) 267279.

14) Ersahin, M. E. and Ozgun, H. (no date) 'Anaerobic Treatment of Industrial Effluents : An Overview of Applications'.

15) Ghafari, S.; Aziz, H.A.; Isa, M. H; Zinatizadeh, A.A: Application of response surface methodology (RSM) to optimize coagulation-flocculation treatment of leachate using poly- aluminum chloride (PAC) and alum, J. Hazard. Mater. 163 (2009) 650-656.

16) Hemalatha, D., Sanchitha, S. and Keerthinarayana, S. (2014) 'Anaerobic Treatment of Pulp and Paper Mill Wastewater Using Hybrid Upflow Anaerobic Sludge Blanket Reactor ( HUASBR )', 3(4), pp. 11576-11584.

17) Jiménez-contreras, E. and Torres-salinas, D. (no date) 'Response Surface Methodology and its application in evaluating scientific activity .'

18) JURADO-ALAMEDA, E., BRAVORODRÍGUEZ, V., BAILÓN-MORENO, R., NUÑEZ-OLEA, J. AND ALTMAJER VAZ, D. (2003), Bath-Substrate-Flow Method for Evaluating the Detersive and Dispersant Performance of Hard- 
Surface Detergents. Industrial and Engineering Chemistry Research, 42: 4303-4310.

19) Korbahti B.K., Tanyolac, A: Electrochemical treatment of simulated textile wastewater with industrial components and Levafix Blue CA reactive dye: Optimization throughresponse surface methodology, Journal of Hazardous Materials 151(2008) 422-431.

20) Kushwaha, J.P.; Srivastava,V.C.; Mall. I.D.: Organics removal from dairy wastewater by electrochemical treatment andresidue disposal, Separation and Purification Technology 76 (2010) 198-205.

21) Lettinga, G., De man, A., Van der last, A.R.M., Wiegant, W., Van knippenberg, K., Frijns, J., Van Buuren, J.C.L., "Anaerobic treatment of domestic sewage and waste water", Water SciTechnol 27, pp.67-73, 1993.

22) Lettinga, G., Van velsen, A.F.M., Hobma, S.W., De zeeuw, W., Klapwijk, A., "Use of the Upflow Sludge Blanket (USB) reactor concept for biological wastewater treatment especially, for anaerobic treatment", BiotechnolBioeng 22, pp.699-734,1980b.

23) Lettinga, G.; van Velsen, A. F. M.; Hobma, S. W.; de Zeeuw, W. \& Klapwijk, A. (1980a). Use of the upflow sludge blanket (USB) reactor concept for biological wastewater treatment, especially for anaerobic treatment. Biotechnology and Bioengineering, 22, 4, 699-734

24) Mandal, T.N., Bandana, T.N., “ Studies on physicochemical and biological characteristics of pulp and paper mill effluents and its impact on human beings", J Freshw Biol 8(4):191-6, 1996.

25) Mohajeri, S.; Aziz, H.A.; Isa, M.H.; Zahed, M.A.; Bashir, M.J.K.; Adlan, M.N: Application of the central composite design for condition optimization for semi-aerobic landfill leachate treatment using electrochemical oxidation. Water Science \& Technology, 61 (2010)1257-1266.

26) Mohajeri, S.; Aziz, H.A.; Zahed, M.A.; Mohajeri, L.; Bashir, M.J.K., Aziz, S.Q.; Adlan, M.N.; Isa, M.H: Multiple responses analysis and modeling of Fenton process for treatment of high strength landfill leachate, Water Science \& Technology, 64 (2011) 1652-1660.

27) Mohamed, M., Matayun, M., Lim, T.S., “ Chlorinated organics in tropical hardwood kraft pulp and paper mill effluents and their elimination in an activated sludge treatment system", Pertanika 2(3), pp.387-94, 1989.

28) MYERS, R.H., MONTGOMERY, D.C., VINING, G.G., KOWALSKI, S.M., AND BORROR, C.M. (2004), Response surface methodology: A retrospective and current literature review. Journal of Quality Technology, 36: 53-77.

29) N. Dichtl, Thermohpilic and mesophilic (two-stage) anaerobic digestion, Water Environ. J. 11 (1997) 98-104.

30) Nemerow, N.L., Dasgupta, A., " Industrial and hazardous waste management", New York: Van Nostrand Reinhold; 1991.

31) O. Ince, Performance of a two-phase anaerobic digestion system when treating dairy wastewater, Water Res. 32 (1998) 2707-2713.

32) Osman, R. M. (2014) 'Anaerobic Fermentation of Industrial Wastewater ( Review Article )', 1(1), pp. 50-78.

33) Pokhrel, D., Viraraghavan, T., "Treatment of pulp and paper mill wastewater - a review" Science of the Total Environment 333, pp.37-58, 2004.

34) Rajakumar, R., Meenambal, T., Rajesh Banu, J., Yeom, I.T., "Treatment of poultry slaughterhouse wastewater in Up flow Anaerobic Filter under low upflow velocity", Int. J. Environ. Sci. Tech., 8(1), pp. 149-158, 2011.

35) Rastegar, S.O.; Mousavi, S.M.; Shojaosadati, S.A.; Sheibani, S: Optimization of petroleum refinery effluent treatment in a UASB reactor using response surface methodology. Journal of Hazardous Materials 197 (2011) 26- 32

36) Rindone, B., Andreoni, V., Rozi, A., Solini, C., "Analysis and anaerobic degradation of wool scouring and olive mill wastewaters", Fresenius J. Anal. Chem. 339, pp.669-672, 1991.

37) Rittmann, B. E. \& McCarty, P. L. (2001). Environmental Biotechnology: Principles And Applications. McGraw-Hill, ISBN: 0072345535, New York, The United States of America.

38) S. Fukuzaki, N. Nish, S. Naga, High rate performance and characterization of granular methanogenic sludges in upflow anaerobic sludge blanket reactors fed with various defined substrates, J. Ferment. Bioeng. 79 (1995) 354-359. 
39) Santos,S.C.R.; Boaventura R.A.R.: Adsorption modelling of textile dyes by sepiolite, Applied Clay Science 42 (2008) 137-145.

40) Speece, R. E. (1996). Anaerobic Biotechnology for Industrial Wastewaters, Archae Press, ISBN: 09650226-0-9, USA BOX, G.B.P., WILSON, K.B. (1951). On experimental attainment of optimum conditions. Journal of the Royal Statistical Society, 13: $1-45$.

41) T. Kobayashi, Y. Li, H. Harada, H. Yasui, T. Noike, Upgrading of the anaerobic digestion of waste activated sludge by combining temperaturephased anaerobic digestion and intermediate ozonation, Water Sci. Technol. 85 (2009) 185-193.

42) Taylor, P., Nnaji, C. C. and Nnaji, C. C. (2013) 'Desalination and Water Treatment $\mathrm{A}$ review of the upflow anaerobic sludge blanket reactor A review of the upflow anaerobic sludge blanket reactor', (June), pp. 37-41. doi: 10.1080/19443994.2013.800809.

43) Tchobanoglous, G.; Burton, F. L. \& Stensel, H. D. (2003). Wastewater Engineering Treatment and Reuse, Metcalf and Eddy, Inc., 4th ed. Revised, McGraw-Hill, ISBN: 0-07-041878-0, New York, USA
44) The World Bank Group, 1999. Pollution prevention and abatement handbook, 1998: toward cleaner. The International Bank for Reconstruction and Development (Washington D.C., United states).

45) Tir, M. Mostefa, N.M. Optimization of oil removal from oily wastewater by electrocoagulation using response surface method, Journal of Hazardous Materials 158 (2008) 107-115.

46) Trinh, T.K.; Kang, L.S: Response surface methodological approach to optimize the coagulation-flocculation process in drinking water Treatment. Chemical Engineering Research and Design 89 ( 201011 ) 1126-1135

47) Wang, J.-P.; Chen,Y.-Z.; Wang, Y.; Yuan, S.-J., $\mathrm{Yu}$, H.Q: Optimization of the coagulationflocculation process for pulp mill wastewater treatment using a combination of uniform design and response surface methodology, Water Research, 45 (2011) 5633-5640.

48) Y. Kiyohara, T. Miyahara, O. Mizuno, T. Noike, K. Ono, A comparative study of thermophilic and mesophilic sludge digestion, Water Environ. J. 14 (2000) 150-154. 